Bangladesh J. Plant Taxon. 16(1): 47-56, 2009 (June)

(C) 2009 Bangladesh Association of Plant Taxonomists

\title{
PTERIDOPHYTES OF GREATER MYMENSINGH DISTRICT OF BANGLADESH USED AS VEGETABLES AND MEDICINES
}

\author{
Sujan Kumer Sarker ${ }^{1}$ and A.B.M. Enayet Hossain \\ Department of Botany, Jahangirnagar University, Savar, Dhaka, Bangladesh. \\ Keywords: Vegetables; Medicine; Pteridophytes; Bangladesh.
}

\begin{abstract}
Sixteen species of pteridophyte, collected from greater Mymensingh district, Bangladesh, were studied for their use as food (vegetables) and traditional herbal medicine. Out of these, four were recorded to have use as vegetables, seven as traditional medicine and five as both vegetables and medicine. Eight species were recorded for the first time in Bangladesh having use as vegetables and/or medicines. The local people and five ethnic communities, namely Coach, Garo, Mandai, Khayatriya and Wera were interviewed in this study.
\end{abstract}

\section{Introduction}

Pteridophytes are vascular cryptogams and form a neglected group of plants in biodiversity as far as their economic value is concerned. Their food and medicinal values are not well known to many of the people of Bangladesh, although their uses as food and medicine are known from earlier literature. Pammel (1911) compiled a manual of poisonous plants from Eastern North America with brief notes on economic and medicinal plants which included some medicinal pteridophytes. The Ayurvedic systems of medicine referred by Sushruta (ca 100 AD) and Charka (ca 100 AD) recommended the medicinal uses of some ferns in their Samhitas. Ferns are also used by the physicians in Unani system of medicine (Uddin et al., 1998). In Chinese system of medicine, many ferns are also prescribed by local doctors (Kimura and Noro, 1965). Later on modern biological and pharmaceutical studies were carried out on pteridophytes by different workers. Benerjee and Sen (1980) conducted the only extensive survey of antibiotic activity among the ferns and reported about a hundred species having such property. Dixit and Vohra (1984) reported edible and medicinally important pteridophytic species from India. Kaushik (1998) emphasized on the ethno-botanical importance of ferns of Rajasthan, India. The ethno-botanical uses of this unique group are of immense importance (Singh et al., 1989; Dhiman, 1998). The most important studies on food and medicinal values of pteridophytes were conducted by Nayar (1957), Hodge (1973), and Dixit (1974, 1975). Recently, Ghosh et al. (2004) reported some edible pteridophytes as vegetables and medicines.

${ }^{1}$ Corresponding author. Present address: Department of Botany, Ananda Mohon Govt. College, Mymensingh, Bangladesh. E-mail: choamoni_97@yahoo.com 
Very recently, it has been recorded that 196 pteridophytic taxa are available in Bangladesh (Siddiqui et al., 2007). Some of them do possess potential value as traditional medicine and food. The study on use of pteridophytes as vegetable and herbal medicine is still in early stage in Bangladesh. This type of work was initiated for the first time in Bangladesh by Uddin et al. (1998). They reported 40 medicinal ferns and fern-allies available in Bangladesh, but did not specify any users or tribal communities in case of medicinal uses. The most important work in Bangladesh on ethno-botanical use of pteridophytes from the Chittagong Hill Tracts was conducted by Uddin et al. (2008) where a total of 40 pteridophytic species were recorded with ethnic importance.

Given the importance of greater Mymensingh from ethno-botanical point of view, an attempt has been made to study the use of pteridophytes of this region as food vegetables and medicines.

\section{Materials and Methods}

The present work is mainly based on materials collected from greater Mymensingh of Bangladesh since 1980's. This study area is very significant for ethno-botanical studies owing to the dominance of different tribal communities, like Coach, Garo, Mandai, Khayatriya and Wera. More than 300 specimens of pteridophyte were collected from the study area through repeated visits in different seasons in different years. In addition to investigation on taxonomic aspects, the association of pteridophytes with the local inhabitants was also considered. For this purpose, a close relationship was built up with local knowledgeable persons and medicine men, and information was collected through interviewing them using pre-tested questionnaire, and, in some cases, through short-term participant observation. Plants were collected from the field as noted by the informants and were preserved as voucher specimens. Information on plant parts used and local uses was recorded on the labels of herbarium sheets. Vernacular and ethnic names of the species and the name(s) of user ethnic group(s) were also recorded. The information given by the informants were cross-checked. Occurrence of species in Bangladesh mentioned here is after Mirza and Rahman (1997), Uddin et al. (2001), Siddiqui et al. (2007) and also authors' personal observations.

In order to authenticate identification of the collected specimens, the specimens preserved in Bangladesh National Herbarium (DACB), Mirpur, Dhaka, Bangladesh and Central National Herbarium (CAL), Botanical Survey of India, Shibpur, Howrah, West Bengal, India were examined. All the collected specimens are stored in Department of Botany, Ananda Mohon Govt. College, Mymensingh and Department of Botany, Jahangirnagar University, Savar, Dhaka, Bangladesh. 


\section{Taxonomic enumeration}

A total of 16 pteridophytic species were found in the study area used as vegetables and medicines by different communities. The species are listed in alphabetical order with their family names and synonyms, followed by short botanical characterization and ecology. For each species vernacular or tribal names (if any), part(s) used, local uses, and occurrence in Bangladesh including the study area are also provided.

1. Adiantum capillus-veneris L., Sp. Pl. 2: 1096 (1753).

(Adiantaceae)

Vernacular name: Bidhayapata. Tribal name: Basanta Lata (Garo).

Tufted, small herb with short creeping rhizome; stipe slender, black, polished. Fronds bi-pinnate with an apical leaflet. Sori marginal, on reflexed marginal flaps of leaflet.

Ecology: Very common on old brick walls, brick-crevices as well as on shady soil of garden and household areas.

Occurrence in Bangladesh: Frequently found throughout Bangladesh.

Part used: Whole plant.

Local uses: The Garo community of Haluaghat and Dhobaura (Mymensingh) take the juice of fresh plants for curing cough and diabetes. Juice of fresh fronds is also taken by their children for good health and against microbial diseases. They keep the plants under bed for the prevention of chicken pox.

2. Ampelopteris prolifera (Retz.) Copel, Gen. Fil.:144 (1947). (Thelypteridaceae) Synonym: Hemionitis prolifera Retz. (1791).

Vernacular name: Dheki Shak.

A creeping or spreading herb, often rooting at the tips of the fronds. Fronds unipinnate. Sori along veins.

Ecology: Grows near water sources, bank of ponds, along roadside slopes and open sunny exposed places.

Occurrence in Bangladesh: Frequently found throughout Bangladesh.

Part used: Young frond.

Local uses: Young or tender fronds are cooked and taken as vegetables by the local people in Mymensingh. This use is recorded for the first time for Bangladesh.

3. Angiopteris evecta (Forst) Hoffm., Comm. Soc. Reg. Gott. 12: 29, t. 5 (1796).

(Angiopteridaceae)

Synonym: Polypodium evectum Forst (1786).

Tribal name: Mati Alu (Khayatriaya). 
A large-sized, semi-erect tree fern, rhizome massive, very thick. Lamina pinnately compound, pinnae costae swollen at their bases, recurrent veins present. Sori exindusiate.

Ecology: Grows on moist slopes near water falls, on deep forest floor.

Occurrence in Bangladesh: Rarely distributed in the hilly regions of Bangladesh. It is found in Chittagong, Dinajpur, Durgapur (Netrokona), Gozni (Sherpur) and Madhabkundu (Sylhet).

Parts used: Frond and rhizome.

Local uses: Young fronds and rhizomes are cooked as vegetables with small fishes or alone and are taken by the Khayatriaya people of Durgapur in Netrakona district. It is also taken by them as an effective purgative against constipation. These uses are recorded for the first time for Bangladesh.

4. Blechnum orientale L., Sp. Pl. 2: 1077 (1753).

(Blechnaceae)

Synonym: Blechnum javanicum Blume (1828).

Tribal name: Baro Dheki Shak (Garo).

A large, terrestrial, erect sun-fern of hilly areas with peculiar circinate vernation, grows up to man-height or more. Fronds pinnately compound. Sori linear, continuous along the costae.

Ecology: Terrestrial, grows generally in open sunny places near hill slopes.

Occurrence in Bangladesh: Very common in the hilly districts of Bangladesh including Chittagong, Jamalpur, Mymensingh, Panchagarh, Sherpur and Sylhet.

Parts used: Frond and rhizome.

Local uses: This species is popularly used as vegetables and ethno-medicine by the Garo of Gozni in Sherpur. The fleshy circinate vernation is burned in flame and is given to children as anthelmintic and abdominal disorders. Fresh fronds are also cooked and taken as vegetables, very effective against constipation. According to Garo beliefs, this species is avoided by all kinds of snakes. These uses are recorded for the first time for Bangladesh.

5. Ceratopteris pteridoides (Hook.) Hiern, Bot. Jahrb. 34: 561 (1905). (Parkeriaceae) Synonym: Parkeria pteridoides Hook. (1825).

Vernacular name: Pani Shak.

Aquatic fern; fronds dimorphic - sterile fronds mostly simple or palmately lobed, fertile fronds dissected. Sori protected by reflexed lamina margin.

Ecology: Aquatic or semi-aquatic mostly rooted on substratum. Grows on humus deposits of old ponds and on the soil of cultivated rice fields. 
Occurrence in Bangladesh: Rarely found in Iswargonj (Mymensingh), Karotia (Tangail), Kendua (Netrokona), Pakundia (Kishoregonj) and Sribordi (Sherpur).

Part used: Frond.

Local uses: Fronds are cooked with other vegetables or alone and are eaten by the rural people of greater Mymensingh district. Fresh fronds are also taken as salad. These uses are recorded for the first time for Bangladesh.

6. Ceratopteris thalictroides (L.) Brongrn. in Bull. Sci. Soc. Philom. Paris, 1821: 186 (1822).

Synonym: Acrostichum thalictroides L. (1753).

Vernacular name: Pani Shak.

Semi-aquatic, tufted fern; fronds dimorphic - sterile fronds lanceolate or deltoid, fertile fronds linear and dissected. Sori protected by reflexed lamina margin.

Ecology: Grows commonly in aquatic habitat, submerged rice fields, sometimes on sub-aquatic soil of shady places.

Occurrence in Bangladesh: Frequently found in greater Chittagong, Cox's Bazar, Dhaka, Jessore, Mymensingh, Rajshahi, Satkhira and Sylhet districts.

Part used: Frond.

Local uses: In the villages of Dhobaura, Nandail, Phulpur and Trisal of Mymensingh fronds are cooked and eaten as vegetables. Fresh fronds are also used as salad.

7. Dicranopteris linearis (Burm.f.) Underw., Bull. Torr. Bot. Club. 34: 250 (1907).

(Gleicheniaceae)

Synonym: Polypodium linearis Burm. (1768).

Tribal name: Khasi Lata (Garo).

A fern of hilly areas; rhizome stout, creeping. Stipes dichotomously branched. Sori simple, two rows on both sides of costa.

Ecology: Terrestrial in hilly areas, growing in open full sunlight or slightly shady roadside slopes, forming dense patches.

Occurrence in Bangladesh: It is widely distributed in the hilly regions of Chittagong, Chittagong Hill Tracts and Sylhet and rarely found in the foot hills of Jamalpur, Mymensingh and Netrakona districts.

Part used: Whole plant.

Local uses: The Garo of Haluaghat (Mymensingh) takes the juice of young leaves for the treatment of cough, allergic symptoms and respiratory troubles. 
8. Diplazium esculentum Retz. Sw., Schrad. J. Bot.1801 (2): 312 (1803).

(Athyriaceae)

Synonym: Hemionitis esculentum Retz. (1791).

Vernacular names: Dheki Shak, Paloi Shak. Tribal name: Teria Shak (Wera).

A herb or small shrub with stout caudex. Fronds bi-pinnate or tri-pinnate. Sori on both sides of the veins with double indusia.

Ecology: Fairly common in moist, shady places by the sides of drain or channel and also grows terrestrially in the homestead areas.

Occurrence in Bangladesh: Frequently found in Bogra, Cox's Bazar, greater Mymensingh, Rangpur and Sylhet.

Part used: Frond.

Local uses: Young fronds are cooked with small shrimps, small fishes or alone and are eaten as a tasty vegetable curry. The users in the study area have confirmed that it is very effective against constipation as a purgative, appetizer and abdominal disorders. The Coach, Garo, Mandai and Wera communities take it as a remedy for skin diseases. The Garo and Wera people also opined that they have got relief from leprosy by taking this species regularly as vegetables. They also take it as a preventive measure against these diseases. These uses are recorded for the first time for Bangladesh.

9. Diplazium polypodioides B1., Enum. P1. Jav.: 194 (1828).

(Athyriaceae)

Synonym: Athyrium asperum (Blume) Milde (1870).

Tribal name: Dheki Shak (Coach, Garo \& Mandai).

A large-sized fern, often giving an impression of a tree fern from a distance. Fronds bi-pinnate or tri-pinnatifid. Sori in two oblique linear rows with thin indusia.

Ecology: Grows in hilly areas in ravines along water courses, often also grows on the forest fringes.

Occurrence in Bangladesh: Distributed in Chittagong, Dinajpur, Durgapur (Netrokona), Gozni, Nalitabari (Sherpur), Lawachapra (Jamalpur), Mymensingh and Sylhet.

Part used: Frond.

Local uses: Fronds with circinate vernation are cooked with dry fish (locally called shutki) or alone as vegetables, taken as delicious food by the Coach and Mandai communities in the foot hill areas of Karnajhura of Lawachapra (Jamalpur), Gozni, Nalitabari (Sherpur) and Haluaghat (Mymensingh). Fresh leaf juice is used for their children as anthelmintic and carminative. These uses are recorded for the first time for Bangladesh. 
10. Drynaria quercifolia (L.) J. Sm. in Hook. J. Bot. 3: 398 (1841). (Polypodiaceae) Synonym: Polypodium quercifolia L. (1753).

Vernacular name: Pankhiraj.

A very common epiphyte with fleshy, creeping rhizome with brown scales. Fronds di-morphic. Sori in two regular rows between lateral veins.

Ecology: Very common epiphyte on raintree, mango tree, palm tree or any other rough-barked trees. Sometime grows on old brick walls, on humus deposits of old tinshed.

Occurrence in Bangladesh: Frequently found throughout Bangladesh.

Part used: Rhizome.

Local uses: Rhizome-paste with coconut oil, applied on head for the treatment of long sleeping disorder by the local people of Phulpur in Mymensingh. It is also used in the treatment of insanity by the local people of Netrakona.

11. Helminthostachys zeylanica (L.) Hook., Gen. Fil.: t. 47(1840).

(Helminthostachyaceae)

Synonym: Osmunda zeylanica L. (1753).

Vernacular name: Kabar Gash.

Eusporangiate fern with fleshy, creeping rhizome and two rounded stipules at the base. Fronds with a tripartite lamina and an erect fertile spike. Sporangia in clusters on short lateral branches.

Ecology: Terrestrial, grows commonly on moist, shady places under bamboo groves, near burial ground and bushy forest floor in plains as well as on the hill slopes.

Occurrence in Bangladesh: Distributed in Chandpur, Chittagong, Chittagong Hill Tracts, Dinajpur, Fulbaria, Muktagacha (Mymensingh), Gozni (Sherpur), Madhupur (Tangail), Sundarban and Sylhet.

Parts used: Frond and rhizome.

Local uses: The village Kabiraj of Fulbaria and Muktagacha in Mymensingh district use paste of the frond and rhizome in the treatment of muscle pain and rheumatism.

12. Lygodium flexuosum (L.) Sw. in Schrad. J. Bot.1800 (2):106 (1801).

(Lygodiaceae)

Synonym: Ophioglossum flexuosum L. (1753).

Tribal name: Poka Lata (Garo \& Mandai).

A terrestrial, climbing fern. Basal leaflets often with large basal lobes. Sporophores dissected on leaf margin; sori surrounded by reflexed leaf margin. 
Ecology: Grows in bushy places, in the plains as well as in the hilly areas.

Occurrence in Bangladesh: Frequently found in Bangladesh including Bogra, Chittagong, Dhaka, Dinajpur, greater Mymensingh and Sylhet.

Part used: Frond.

Local uses: Juice of fronds is applied to wounds or cuts by the Garo and Mandai in Madhupur and Haluaghat. Frond-paste is also applied externally to insect bite by the local people of Jhinaigati and Gozni (Sherpur).

13. Marsilea minuta (L.) Mant., 308(1771).

(Marsileaceae)

Synonym: Marsilea aegyptiaca Wall. (1828).

Vernacular and tribal name: Shusni Shak (Coach \& Garo).

Aquatic or sub-aquatic fern with creeping rhizome. Lamina quadrifoliate with long stipe. Gradate sori in sporocarp.

Ecology: Grows in drain water, ditches on lowland and on the cultivated rice fields. Sporocarps produced only in amphibious condition.

Occurrence in Bangladesh: Frequently found throughout Bangladesh.

Part used: Whole plant.

Local uses: The rural people of Mymensingh eat the fronds as vegetable and they have got relief from hypertension, sleeping disorders and headache by regular eating. In Haluaghat and Dhobaura of Mymensingh district the Garo and Coach drink the juice of fresh shoots as a remedy for cough, respiratory troubles, especially for their babies. Juice or paste of the whole plant are applied externally on the head of patients suffering from sleeping disorder and hypertension; the patients reported that they have got relief from sleeping disorder and hypertension.

14. Microlepia strigosa (Thunb.) Presl, Epim. Bot.: 95 (1851). $\quad$ (Dennstaedtiaceae) Synonym: Trichomanes strigosum Thumb. (1784).

Tribal name: Dheki Shak (Coach \& Garo).

A big-sized, tufted fern with bipinnate fronds. Sori cup-shaped, sub-marginal with a few hairs.

Ecology: Terrestrial, grows generally in the hilly areas in tufts.

Occurrence in Bangladesh: Occurs in abundance in the foot hill areas of Chittagong Hill Tracts, Gozni (Sherpur), Lawachapra (Jamalpur) and Sylhet.

Part used: Frond.

Local uses: Young fronds are cooked as vegetables, taken by the Coach and Garo of Gozni and Lawachapra. This use is recorded for the first time for Bangladesh. 
15. Nephrolepis cordifolia (L.) Presl, Tent. Pterid.: 79 (1836). $\quad$ (Nephrolepidaceae) Synonym: Polypodium cordifolium L. (1753).

Vernacular name: Bagan Fern.

Frond tufted and pinnately compound, pinnae opposite, sessile, base cordate. Sori in two rows along the vines.

Ecology: Terrestrial, grows in shady places, commonly cultivated in gardens.

Occurrence in Bangladesh: Distributed in Chittagong, Dhaka, Dinajpur, Jamalpur, Mymensingh, Netrokona, Sherpur and Sylhet.

Parts used: Frond and tuber.

Local uses: Some of the herbal practioners of Sherpur, Mymensingh and Netrokona districts use the extract of frond and tuber-paste for the treatment of cough, allergic symptoms and respiratory troubles.

16. Pityrogramma calomelanos (L.) Link, Handb. Erken. Gew. 3: 20 (1833).

(Hemionitidaceae)

Synonym: Acrostichum calomelanos L. (1753).

Vernacular name: Matka Pata (Garo).

A tufted fern with dark purplish shining stipes. White farinose on lower surface of pinnules. Sori on the lower surface of pinnules covering it completely.

Ecology: Terrestrial, grows commonly on shady soil of hill slopes, along water canals and cultivated as a pot-plant.

Occurrence in Bangladesh: Frequently found in greater Mymensingh, Gozni (Sherpur), Lawachapra (Jamalpur) and also in Chittagong, Dinajpur, Moulvi Bazar, Panchagarh and Sylhet.

Part used: Frond.

Local uses: The Garo herbal practioners of Gozni, Nalitabari and Runctia (Sherpur) use frond-paste for treatment of backache, joint and muscle pain of legs. This use is recorded for the first time for Bangladesh.

\section{References}

Benerjee, R.D. and Sen, S.P. 1980. Antibiotic activities of Pteridophytes. Ec. Bot. 34(2): 284-298.

Dhiman, A.K. 1998. Ethnomedicinal uses of some Pteridophytic species in India. Indian Fern. J. 15: 61-65.

Dixit, R.D. 1974. Ferns - a much neglected group of medicinal plants. I. J. Res. Indian Med. 9(4): 59-68.

Dixit, R.D. 1975. Ferns - a much neglected group of medicinal plants. III. J. Res. Indian Med. 10(2): 74-90.

Dixit, R.D. and Vohra, J.N. 1984. A Dictionary of the Pteridophytes of India (Flora of India Series 4) Botanical Survey of India Publication, Department of Environment, Government of India, Botanical Garden, Howrah, pp. 1-177. 
Ghosh, S.R., Ghosh, B., Biswas, A. and Ghosh, R.K. 2004. The Pteridophytic Flora of Eastern India (Vol. 1). Flora of India Series 4. Botanical Survey of India, pp. 1-591.

Hodge, W.H. 1973. Fern food of Japan and the problem of toxicity. Amer. Fern. J. 63: 77-80.

Kaushik, P. 1998. Ethnobotanical Importance of Ferns of Rajsthan: Indigenous Medicinal Plants. Today and Tommorrow Printers and Publication, New Delhi, pp. 61-66.

Kimura, K. and Noro, Y. 1965. Pharmacognostical studies on Chinese drug "Gu-sui-bu". I. consideration on "gu-sui-bu" in old herbals (Pharmacognostical studies on fern drugs XI). Syoy - akugaku Zasshi 19: 2531.

Mirza, M.M. and Rahman, M.M. 1997. An annotated checklist of ferns and fern-allies of Bangladesh. Bangladesh J. Plant Taxon. 4(2): 47-69.

Nayar, B.K. 1957. Medicinal ferns of India. Bull. Nat. Bot. Gdn. 58: 1-38.

Pammel, L.H. 1911. A Manual of Poisonous Plants - Chiefly of Eastern North America with Brief Notes on Economic and Medical Plants and Numerous illustrations. The Torch Press Cedar Rapdis, Iowa, pp. 323-325.

Rao, R.R. and Hajra, P.K. 1995. Methods of research in Ethnobotany. In: Jain, S.K. (ed.), A Manual of Ethnobotany. Sci. Pub. Jodhpur, India, pp. 28-34.

Siddiqui., K.U., Islam, M.A., Ahmad, Z.U., Begum, Z.N.T., Hassan, M.A., Khondker, M., Rahaman, M.M., Kabir, S.M.H., Ahmad, M., Ahmed, A.T.A., Rahman, A.K.A. and Haque, E.U. (eds) 2007. Encyclopedia of Flora and Fauna of Bangladesh. Vol. 5. Pteridophyta, pp. 195-342, Asiatic Society of Bangladesh, Dhaka.

Singh, K.K., Saha, S. and Maheshwari, J.K. 1989. Ethnomedicinal uses of some ferns amongst the tribals of Uttar Pradesh. Indian Fern J. 6: 66-67.

Uddin, M.G. Mirza, M.M. and Pasha, M.K. 1998. The medicinal uses of pteridophytes of Bangladesh. Bangladesh J. Plant Taxon. 5(2): 29-41.

Uddin, M.G., Rahman, M.M., Sarker, S.K. and Pasha, M.K. 2001. A systematic account of the pteridophytic flora of greater Mymensingh District of Bangladesh. Bangladesh J. Plant. Taxon. 8(1): 65-80.

Uddin, S.B., Rahman, M.A., Uddin, M.G. and Pasha, M.K. 2008. Ethno-botancial uses of Pteridophyte from Chittagong Hill Tracts of Bangladesh. Nepal Journal of Plant Science 2(1): 89-93.

(Manuscript received on 16 September 2008; revised on 1 April 2009) 